\title{
Changes following nipple areolar complex reconstruction and tattooing resembling a recurrent Paget's disease of the breast
}

\author{
Mohammad Hanafiah, ${ }^{1}$ Sharifah Majedah Idrus Alhabshi, ${ }^{2}$ Aznil Hisham Mahin ${ }^{2}$
}

${ }^{1}$ Department of Radiology, MARA University of Technology Clinical Training Centre, Sungai Buloh, Selangor, Malaysia ${ }^{2}$ Department of Radiology, University Kebangsaan Malaysia Medical Centre, Cheras, Kuala Lumpur, Malaysia

\section{Correspondence to} Dr Sharifah Majedah, shmajedah@yahoo.com
CrossMark

To cite: Hanafiah $\mathrm{M}$, Alhabshi SMI, Mahin AH BMJ Case Rep Published online: [please include Day Month Year] doi:10.1136/ bcr-2013-201281

\section{DESCRIPTION}

We present a case with images of a 50-year-old woman who was initially presented with Paget's disease of the right breast. She then underwent a wide local excision and nipple removal of the affected breast followed by transverse rectus abdominis myocutaneous flap surgery with nipple areolar complex (NAC) reconstruction and tattooing. The 6-month postoperative follow-up revealed an irregular lump at the retroareolar region of the same breast associated with mild pain. On further enquiry, she claimed that the lump first appeared after the tattooing and it grew slightly larger and became discrete months later.

On examination there was a non-tender, firm and irregular mass at the retroareolar region of the right breast. Part of the tattoo pigmentation at the reconstructed NAC region has faded with ill-defined margin (figure 1). Mammogram in craniocaudal and mediolateral-oblique views of the right breast showed irregular high-density mass at the region of the NAC, extending to the overlying skin (figure 2). Ultrasound of the left breast showed an ill-defined mass $(3.0 \mathrm{~cm} \times 2.5 \mathrm{~cm})$ with heterogeneous internal echo and posterior acoustic shadowing at the right reconstructed NAC region (figure 3). Doppler study showed minimal vascularity.

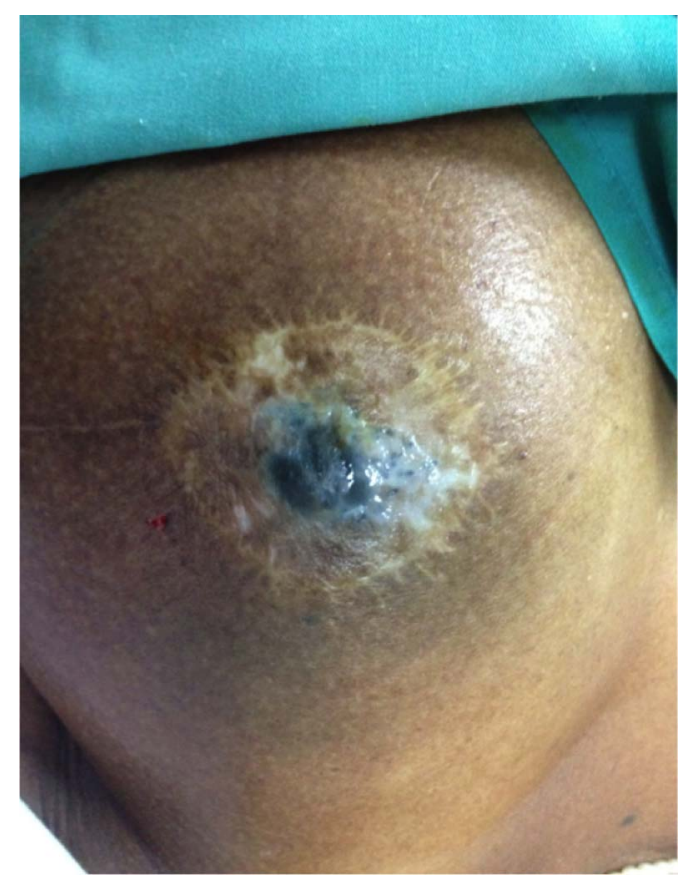

Figure 1 Image of the right breast postnipple areolar complex reconstruction and nipple tattooing. The tattoo is faded with irregular outline.

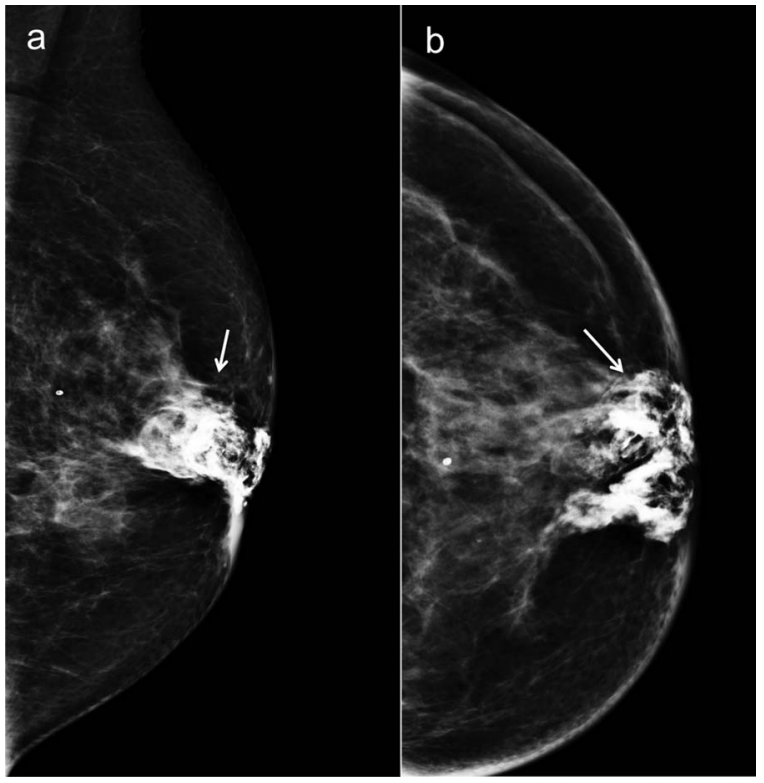

Figure 2 Mammogram of the right breast. (A) Craniocaudal and (B) mediolateral oblique views showing an irregular high-density mass at the retronipple areolar complex region, which extends to the skin (arrow). 


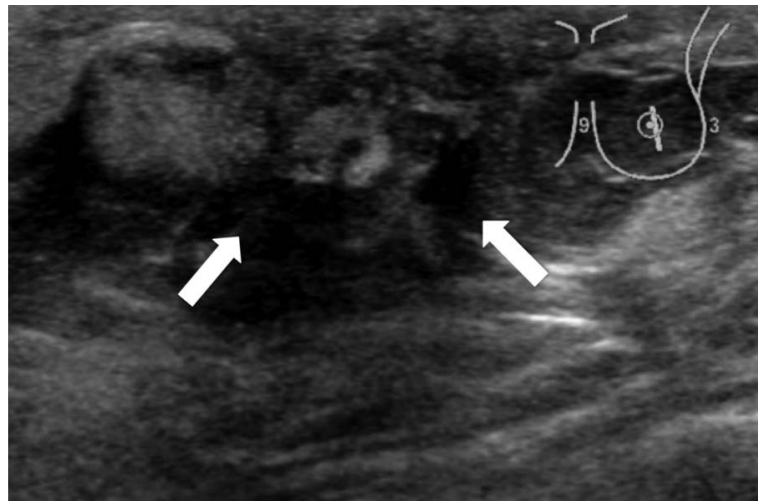

Figure 3 Ultrasound of the left breast showing an ill-defined mass with heterogenous internal echo and posterior acoustic shadowing at right retronipple areolar complex region.

Owing to the indeterminate nature of the mass and recent history of Paget's disease of the breast, a core biopsy was performed. The histopathological result revealed fibrocollagenous tissue containing abundant dense blackish carbon pigments within the macrophages and the background stroma. Fibroblasts and dilated vessels with scattered lymphocytes and plasma cells were also seen. Otherwise, no malignant cells were detected. Follow-up sonographic study that was performed 6 months later showed no further progression of the changes, representing the benign nature of the lesion. The overall findings are compatible with intradermal healed foreign body reaction and secondary fibrosis following to nipple tattooing.

NAC reconstruction and dermal tattooing is usually performed as an adjunct to a breast reconstruction with the aim to restore the patient's body image. Dermal tattooing involves the introduction of non-absorbable pigments into the dermis, which are phagocytised by the macrophages and, in turn, stored intracellularly in the fibroblasts within the dermis. Intolerance reactions against a dermal tattoo may be seen and the clinical picture is quite heterogeneous and can resemble eczematous, lichenoid, pseudolymphomatous or granulomatous lesions. ${ }^{1}$ The extent and risk of this effect is generally low and depends on the chemical origin of the pigments. ${ }^{2}$ The present case demonstrated that a healed foreign body reaction following nipple tattooing might be presented as an irregular intradermal mass due to scarring and granulation tissue formation. The clinical and imaging findings may mimic a suspicious lesion, such as tumour recurrence, as exemplified here.

\section{Learning points}

- Postforeign body reaction and scarring/granulation tissue formation following a nipple areolar complex tattooing can mimic suspicious lesion in the breast.

- Mammogram may reveal the lesion as high density due to the engulfed tattoo pigments.

- Sonographic study is a simple, low-risk and reliable modality for follow-up purposes.

- For indeterminate and high-risk case, core biopsy is mandatory for confirmatory diagnosis.

Contributors All authors have equal contribution in drafting, writing revising and completing the manuscript.

Competing interests None.

Patient consent Obtained.

Provenance and peer review Not commissioned; externally peer reviewed.

\section{REFERENCES}

1 Kaatz $M$, Elsner $P$, Bauer $A$. Body-modifying concepts and dermatologic problems: tattooing and piercing. Clin Dermatol 2008;26:35-44.

2 Farhadi J, Maksvytyte GK, Schaefer DJ, et al. Reconstruction of the nipple-areola complex: an update. J Plast Reconstr Aesthet Surg 2006;59:40-53.

Copyright 2013 BMJ Publishing Group. All rights reserved. For permission to reuse any of this content visit http://group.bmj.com/group/rights-licensing/permissions.

BMJ Case Report Fellows may re-use this article for personal use and teaching without any further permission.

Become a Fellow of BMJ Case Reports today and you can:

- Submit as many cases as you like

- Enjoy fast sympathetic peer review and rapid publication of accepted articles

- Access all the published articles

- Re-use any of the published material for personal use and teaching without further permission

For information on Institutional Fellowships contact consortiasales@bmjgroup.com

Visit casereports.bmj.com for more articles like this and to become a Fellow 